\title{
DETERMINASI KINERJA MANAJER PUSAT LABA HOTEL DI KOTA MAKASSAR
}

\author{
Syamsu Alam \\ Dosen Fakultas Ekonomi Universitas Muslim Indonesia Makassar \\ e-mail:ancu_alam@yahoo.com
}

ABSTRAK

Penelitian ini akan melihat ketidakpastian lingkungan, karakteristik anggaran dan job relevant information, sebagai faktor yang menstimulus kinerja menajer. Subjek pene-litian ini adalah manajer food and beverage hotel berbintang di kota Makassar. Peneli-tian ini dilakukan dalam rangka memperoleh bukti empiris atas studi analisis yang menguji pengaruh interaksi persepsi ketidakpastian lingkungan, karakteristik anggaran dan job relevant information terhadap kinerja manajerial.Diharapkan penelitian ini bermanfaatbagi akademik sebagai bahan informasi tambahan bagi para mahasiswa serta dapat memberi wawasan dan gambaran mengenai konsepkonsep kondisi lingkungan, karakteristik anggaran, job relevant information dan kinerja manajer.

Penelitian ini dilakukan pada seluruh hotel bintang tiga di Kota Makassar, pada tahun 2017. Objek dalam penelitian ini yaitu ketidakpastian lingkungan, karakteristik anggaran, dan job relevant information. Data dalam penelitian ini mengunakan data primer diperoleh secara langsung dari sumber asli dengan menggunakan kuesioner. Populasi sasaran dalam penelitian ini adalah seluruh manajer pada Hotel ber bintang tiga di Kota Makassar berjumlah 22. Unit analisis yang sekaligus menjadi responden dalam penelitian ini adalah Seluruh Manajer Food and Baverage. Analisa data dalam penelitian ini dilakukan dengan menggunakan regresi linier berganda.

Hasil analisis data menunjukkan koefisien regresi ketidakpastian lingkungan sebesar -0,397, artinya jika variabel ketidakpastian lingkungan bertambah satu satuan maka kinerja manajer akan menurun sebesar 0,397. Koefisien regresi karakteristik anggaran sebesar 0,554, artinya jika variabel karakteristik anggaran bertambah satu satuan maka kinerja manajer akan meningkat sebesar 0,554. Koefisien regresi job relevant information sebesar 0,175 , artinya jika variabel job relevant information bertambah satu satuan maka kinerja manajer akan meningkat sebesar 0,175.

Keyword : Ketidakpastian lingkungan, Karakteristik Anggaran, Job Relevant Information, Kinerja Manajer

\section{PENDAHULUAN}

Manajer bekerja dengan dan melalui orang lain dengan mengoordinasikan kegiatan-kegiatan pekerjaan guna mencapai tujuan organisasi. Banyak karyawan yang percaya dan berharap keterlibatan manajer dapat menjadi pendorong bagi penyelesasian masalah yang dihadapi oleh suatu organisasi, baik itu organisasi 
bisnis, depertemen (divisi) tertentu dalam sebuah perusahaan, dan sebagainya.(Arfan, 2010).

Mahoney dalam Eko (2012) menjelaskan bahwa anggota organisasi yang berperan menjalankan fungsi manajerial adalah para manajer.Para manajer di tuntut untuk berimprovisasi dalam menetapkan sasaran dalam mencapai tujuan organisasi. Peningkatan kinerja manajer distimulus oleh faktor-faktor, antara lain kondisi lingkungan, anggaran operasional, dan informasi akuntansi.

Kualitas dari sebuah instutusi dapat terjaga apabila perusahaan tersebut mampu mengambil keputusan-keputusan strategi yang efektif dan efisien, serta selalu berusaha untuk menyesuaikan diri dengan keadaan dan perkembangan yang ada. Pengambilan keputusan tersebut berkaitan dengan kinerja manajerial perusahaan termasuk dalam hal ini institusi perusahaan privat seperti hotel.

Hotel merupakan suatu entitas manajemen yang makin strategis fungsinya seiring dengan berkembangnya dunia bisnis lainnya di berbagai tempat.Pada akhirnya, hotel semakin menunjukkan eksistensinya disamping sebagai wadah untuk menunjang sektor bisnis yang lainnya, juga sebagai institusi pencipta kekayaan yang senantiasa menjaga kelangsungan hidupnya melalui pengambilan keputusan bisnis yang tepat dan penciptaan kinerja yang baik dari seorang manajer.

Dalam usaha mewujudkan kinerja yang baik, para manajer hotel dihadapkan pada kondisi lingkungan dan kebutuhan informasi akuntansi manajemen. Ketersediaan informasi akuntansi manajemen ini akan membantu manajemen dalam mengambil keputusan internal, atau sebaliknya bisa memicu perilaku disfungsional sebagai akibat informasi yang overload (Gerloff, 1985).

Usaha perhotelan memiliki kondisi lingkungan yang berbeda dibanding dengan jenis perusahaan yang lain. Perusahaan ini bisa distimulus oleh kepekaan dengan situasi politik dan ekonomi dan kemajemukan intern organisasi yang melibatkan para manajer multikultur yang menjadi lingkungan perusahaan. Artinya, jika situasi politik ekonomi mengalami perubahan situasi, maka akan berdampak pada situasi perusahaan tersebut.

Selain ketidakpastian lingkungan, karakteristik anggaran juga mempengaruhi kinerja manajer seperti partisipasi anggaran, kejelasan sasaran anggaran, umpan balik anggaran, evaluasi anggaran.Hal ini tentu tidak lepas dari fungsi anggaran sebagai alat pengendalian dan sebagai alat untuk mengedukasi manajemen untuk menjalankan tugasnya dan berusaha mencapai tujuan-tujuan organisasinya.

Job relevant information (JRI) merupakan informasi yang dapat membantu manajer dalam memilih tindakan yang terbaik melalui upaya yang diinformasikan secara lebih baik misalnya kondisi perekonomian dan kondisi keuangan internal organisasi.Dalam hal ini JRI memberikan pengetahuan yang lebih baik bagi manajer mengenai alternatif keputusan dan tindakan yang dibutuhkan untuk mencapai tujuan. Tersedianya JRI akan membantu manajer untuk membuat keputusan penting serta dapat membantu manajer untuk memprediksi keadaan lingkungan organisasi secara tepat sehingga dapat meningkatkan kinerja manajerialnya (Ginanjar, 2014).

Penelitian ini akan melihat ketidakpastian lingkungan, karakteristik anggaran dan job relevant information, sebagai faktor yang menstimulus kinerja menajer. 
Subjek penelitian ini adalah manajer food and beverage hotel berbintang di kota Makassar.

Berdasarkan uraian ini maka dirumuskan masalah sebagai berikut: 1) apakah kondisi lingkungan berengaruh terhadap kinerja manajer pada hotel bintang di kota Makassar; 2) apakah karakteristik anggaran berpengaruh terhadap kinerja manajer pada hotel bintang di kota Makassar; 3) apakah job relevant information berpengaruh terhadap kinerja manajer pada hotel bintang di kota Makassar.

Penelitian ini dilakukan dalam rangka memperoleh bukti empiris atas studi analisis yang menguji pengaruh interaksi persepsi ketidakpastian lingkungan, karakteristik anggaran dan job relevant information terhadap kinerja manajerial.

Diharapkan penelitian ini bermanfaatbagi akademik sebagai referensi dan bahan informasi tambahan bagi para mahasiswa serta dapat memberi wawasan dan gambaran mengenai konsep-konsep kondisi lingkungan, karakteristik anggaran, job relevant information dan kinerja manajer. Begitu pula, sebagai bahan bacaan atau literatur tambahan bagipeneliti yang lain untuk mengembangkan kajian selanjutnya.

\section{Grand Theory}

Grand theory yang mendasari penelitian ini adalah stewardship theory, yang menggambarkan situasi dimana para manajemen tidaklah termotivasi oleh tujuantujuan individu tetapi lebih ditujukan pada sasaran utama untuk kepentingan organisasi. Teori tersebut mengasumsikan adanya hubungan yang kuat antara kepuasan dan kesuksesan organisasi. Kesuksesan organisasi menggambarkan maksimalisasi utilitas kelompok principals dan manajemen.

Teori ini bertujuan untuk meningkatkan kemampuan individu baik principal maupun agen dalam mengevaluasi lingkungan dimana keputusan harus diambil, dan untuk mengevaluasi dari hasil keputusan yang telah diambil guna mempermudah pengalokasian hasil antara prinsipal dan agen sesuai dengan kontrak kerja.

Prinsipal mempekerjakan agen untuk melaksanakan tugas termasuk pengambilan keputusan dan lingkungan yang tidak pasti.Agen sebagai seorang manager akan mengambil keputusan untuk melakukan berbagai strategi guna mempertahankan kelangsungan usaha perusahaan.

\section{Ketidakpastian lingkungan}

Ketidakpastian lingkungan merupakan faktor penting karena kondisi demikian dapat menyulitkan perencanaan dan pengendalian. Perencanaan menjadi bermasalah dalam situasi operasi yang tidak pasti karena tidak terprediksinya kondisi masa mendatang. Gordon (1984) menyatakan pentingnya informasi yang berorientasi ke depan bagi manajer yang sedang menghadapi ketidakpastian. Sementara, Chenhall (1986) menekankan hahwa dalam kondisi seperti itu dibutuhkan informasi yang agregatnya luas, tepat waktu. Hal ini sangat logis karena manajer terdesentralisasi, membutuhkan informasi yang bermanfaat untuk mengarahkan dan memecahkan masalah, seperti penetapan harga, pemasaran dan kontrol persediaan. 
Ketidakpastian lingkungan sering menjadi faktor yang menyebabkan organisasi melakukan penyesuaian terhadap kondisi organisasi dengan lingkungan. Individu akan mengalami ketidakpastian lingkungan yang tinggi jika merasa lingkungan tidak dapat diprediksi bagaimana komponen lingkungan akan berubah (Milliken, 1987). Dalam lingkungan yang dinamis, dimana peraturan pemerintah yang berubah-ubah, munculnya pesaing baru, sulit memprediksi lingkungan eksternal. Kondisi seperti ini mengakibat-kan proses perencanaan dan pengendalian akan menjadi lebih sulit karena kejadian yang akan datang semakin sulit untuk diperkirakan.

\section{Karakteristik Anggaran}

Menurut Kenis (1979) dalam Istiyani (2009), ada 5 (lima) karakteristik anggaran (Budgetary Characteristics) yaitu: 1) pertisipasi anggaran; 2) kejelasan anggaran; 3) umpan balik anggaran dan 4) evaluasi anggaran. Partisipasi berarti peran serta seseorang atau masyarakat dalam bentuk pernyataan maupun dalam kegiatan dengan memberi masukan pikiran, tenaga, waktu, keahlian, modal dan atau materi. Argyris (1964) dalam Nor (2007) menyatakan bahwa partisipasi sebagai alat untuk mencapai tujuan, partisipasi juga sebagai alat untuk mengintegrasikan kebutuhan individu dan organisasi.

Kejelasan anggaran artinya tujuan anggaran dinyatakan secara spesifik, jelas dan dapat dimengerti. Kejelasan anggaran diharapkan dapat membantu manajer untuk mencapai tujuan perusahaan sebagaimana yang tercantum dalam perencanaan anggaran, sehingga secara logis kinerja dapat tercapai.Umpan balik anggaranberperan untuk menyajikan informasi bagi yang bertang-gungjawab dalam mengkonsumsi sumber daya untuk mencapai sasaran anggaran. Umpan balik mengenai tingkat pencapaian tujuan anggaran efektif memperbaiki kinerja dan sikap manajer (Kenis, 1979).

Evaluasi anggaranartinya tindakan yang dilakukan untuk menelusuri penyimpangan atas anggaran sebagai dasar untuk penilaian kinerja (Kenis, 1979). Hal ini akan mempengaruhi tingkah laku, sikap dan kinerja manajer. Evaluasi anggaran dapat terjadi karena adanya perkembangan baru, umpan balik dan kesalahan. Ketika anggaran dievaluasi maka akan didapat suatu perbandingan antara apa yang telah dianggarkan dengan yang telah dicapai.

\section{Job Relevant Information}

Job-relevant information (JRI) merupakan informasi yang dapat membantu manajer dalam memilih tindakan yang terbaik melalui upaya yang diinformasikan secara lebih baik (Ginanjar, 2014). JRI dapat meningkatkan kinerja karena memberikan prediksi yang lebih akurat mengenai keadaan lingkungan yang memungkinkan dilakukannya serangkaian tindakan yang lebih efektif untuk melakukan tindakan terbaik.

Tersedianya informasi yang berhubungan dengan tugas akan meningkatkan peren-canaan untuk mencapai tujuan yang ditetapkan, yang pada akhirnya akan meningkatkan kinerja manajer. Job Relevant Information sangat dibutuhkan untuk mengambil langkah strategis dalam pencapaian tujuan yang telah ditetapkan (Kren,1992). 


\section{Kinerja Manajer}

Kinerja manajer adalah tingkat kecakapan manajer dalam melaksanakan aktifitas manajemen yangmeliputi perencanaan, investigasi, pengkoordinasian evaluasi, pengawasan, pemilihan staf, negosiasi,perwakilan, kinerja secara menyeluruh. Dapat disimpulkan bahwa kinerja manajerial adalahhasil kerja secara kualitas dan kuantitas yang dicapai oleh seseorang manajer dalam melaksanakan tugasnyasesuai dengan tanggung jawab yang diberikan kepadanya.

Menurut Anwar (2012), kinerja merupakan hasil kerja secara kualitas dan kuantitas yang dicapai oleh seorang karyawan dalam melaksanakan tugasnya sesuai dengan tanggung jawab yang diberikan kepadanya.

Berikut ini beberapa ukuran yang digunakan untuk mengevaluasi kinerja manajemen, berdasarkan perspektif non keuangan: 1) Kemampuan manajer untuk membuat perencanaan Schermerhorn dalam I Made (2003) Perencanaan yang baik dapat meningkatkan fokus dan fleksibilitas manajer dalam manangani pekerjaannya; 2) Kemampuan untuk mencapai target. Kinerja manajer dapat diukur dari kemampuan mereka untuk mencapai apa yang telah direncanakan Mulyadi dalam I Made (2003) Kiprah manajer di luar perusahaan. Intensitas manajer dalam mewakili perusahaan untuk berhubungan dengan pihak luar menunjukkan kepercayaan perusahaan kepada manajer tersebut. Kepercayaan ini dapat timbul karena beberapa hal, salah satunya adalah kinerja yang baik dari manajer.

\section{Hipotesis}

Berdasarkan kajian teoritis tersebut, maka hipotesis akan dibangun dengan meng-kaitkan konsep ketidakpastian lingkungan, karakteristik anggaran dan job relevant information dengan kinerja manajer dengan kerangka pemikiran sebagai berikut :

\section{Pengaruh Ketidakpastian Lingkungan terhadap Kinerja Manajer}

Chenhall (1986) menemukan jika ketidakpastian lingkungan meningkat, manajer akan mempertimbangkan menggunakan informasi eksternal, dan non keuangan dalam pengambilan keputusan. Miah (1996), mengatakan penggunaan informasi akuntansi manajemen lingkup luas dan ketidakpastian lingkungan yang meningkat berpengaruh secara positif terhadap kinerja manajerial karena manajer dapat lebih berkonsentrasi dalam melaksanakan tugas-tugas rutin mereka. Gul (1991) menyimpulkan bahwa pada level ketidakpastian lingkungan yang tinggi, informasi akuntansi manajemen yang kompleks berpengaruh secara positif pada kinerja manajer, tetapi di bawah level ketidapastian yang rendah, informasi tersebut mempunyai pengaruh negatif. Penelitian lain menemukan Ketidakpastian lingkungan berpengaruh langsung secara positif terhadap kinerja (Porter, 1979).

Hipotesis 1: Ketidakpastian lingkungan mempunyai pengaruh signifikan terhadap kinerja manajer.

\section{Pengaruh Karakteristik Anggaran terhadapa Kinerja Manajer}

Kenis (1979) menyatakan bahwa partisipasi penyusunan anggaran, kejelasan tujuan anggaran dan umpan balik anggaran berpengaruh positif terhadap sikap dan 
kinerja manajer. Maryanti (2002) mengembangkan penelitian Kenis (1979) menyebutkan bahwa evaluasi anggaran, umpan balik anggaran, dan kejelasan tujuan anggaran mempunyai pengaruh positif terhadap perilaku, sikap dan kinerja aparat pemerintah daerah di Propinsi NTT.

Citra (2006) menunjukkan bahwa budgetary goal characteristics berpengaruh terhadap kinerja manajerial. Ratna (2009) menunjukkan bahwa partisipasi penyusunan anggaran berpengaruh terhadap kinerja manajerial. Menurut Bambang (2007) terdapat pengaruh yang signifikan antara partisipasi penyusunan anggaran terhadap kinerja aparat pemerintah daerah.

Munawar (2006) menemukan bahwa evaluasi anggaran berpengaruh terhadap perilaku aparat pemerintah daerah Kab. Kupang. Hal ini menunjukkan bahwa dalam menyiapkan anggaran mereka selalu melakukan evaluasi kegiatan yang telah diprogramkan dan pada pelaksanaan anggaran, mereka juga melakukan evaluasi terhadap kegiatan yang telah dilakukan sehingga kinerja mereka menjadi lebih baik.

Hipotesis 2: Karakteristik anggaran mempunyai pengaruh signifikan terhadap kinerja manajer.

\section{Pengaruh Job Relevant Information terhadap kinerja manajer}

Rosidi (2000) membuktikan bahwa variabel jobrelevant information berpengaruh secara positif dan signifikan terhadap prestasi kerja. Chong (2002) membuktikan bahwa JRI dan kinerja manajerial berhubungan positif dan signifikan. Indarto (2011), menunjukkan bahwa Job Relevant Information secara signifikan berhubungan dengan kinerja manajerial.

Penelitian Selfi (2016) menemukan bukti bahwa JRI memiliki pengaruh yang signifikan terhadap kinerja manajerial. Hal tersebut berarti bahwa job-relevant information yang tinggi berhubungan dengan tingginya kinerja manajerial.

Hipotesis 3: Job relevant information mempunyai pengaruh signifikan terhadap kinerja manajer.

Berdasarkan uraian tersebut, maka model penelitian yang dibangun terdapat dalam gambar di bawah ini yang menjelaskan kerangka pemikiran teoritis yang menggambarkan pengaruh ketidakpastian lingkungan, karakteristik anggaran dan adanya job relevant information terhadap kinerja manajer.

\section{Gambar 1.}

\section{Model Penelitian}

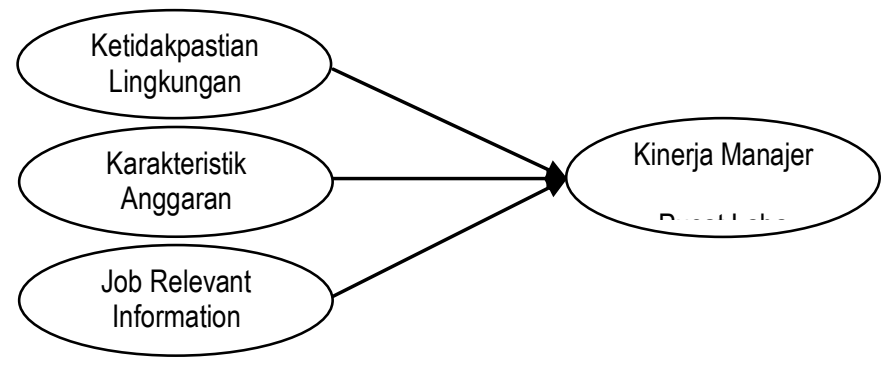




\section{METODE PENELITIAN}

\section{Lokasi dan Waktu Penelitian}

Penelitian ini dilakukan pada seluruh hotel bintang tiga di Kota Makassar, sedangkan waktu penelitian yang diperlukan yaitu selama kurang lebih 2 bulan terhitung mulai bulan Mei-Juni 2017.

\section{Objek Penelitian}

Objek penelitian ini terdiri dari dua yaitu independen/bebas yaitu ketidakpastian lingkungan, karakteristik anggaran, dan job relevant information. Adapun variabel dependen/ terikat dalam penelitian ini adalah kinerja manajer. Sehubungan dengan objek penelitian tersebut, maka yang dijadikan subjek penelitian ini adalah hotel bintang di Kota Makassar.

\section{Definisi Operasional Variabel}

1. Kinerja Manajer (Y) adalah tingkat kecakapan manajer dalam melaksanakan aktifitas manajemen. Indikator variabelnya meliputi: perencanaan, investigasi, koor-dinasi, evaluasi, supervisi, staffing, negosiasi, perwakilan. Indikator ini dikembang-kan berdasarkan pertanyaan yang dikembangkan oleh Mahoney (1965), dan telah digunakan secara luas.

2. Ketidakpastian lingkungan $\left(\mathbf{X}_{1}\right)$ adalah ketidakpastian lingkungan eksternal yang dirasakan oleh manajer karena ia tidak dapat memprediksinya keadaan organisasi di masa depan. Indikator variabel yaitu: ketidakpastian ekonomi dan politik, ketidakpastian hukum dan peraturan, ketidakpastian atas tindakan demonstrasi masyarakat yang menentang kebijakan pemerintah daerah, kondisi ekternal non keuangan, memprediksi kebutuhan informasi. Indikator ini diadaptasi dari indikator yang telah digunakan oleh Gordon (1984).

3. Karakteristik Anggaran $\left(\mathbf{X}_{2}\right)$.Anggaran merupakan suatu rencana kuantitatif tertulis mengenai kegiatan organisasi. Anggaran harus disusun dan dihitung dengan cermat agar operasionalisasi baik perusahaan besar maupun kecil dapat berjalan dengan efektif. Untuk mewujudkan hal tersebut anggaran harus memiliki karakteristik tertentu.Menurut Kenis (1979) dalam Istiyani (2009), ada 5 (lima) karakteristik anggaran (Budgetary Characteristics) yaitu: 1) pertisipasi anggaran; 2) kejelasan anggaran; 3) umpan balik anggaran dan 4) evaluasi anggaran.

4. Job Relevant Information $\left(\mathbf{X}_{\mathbf{3}}\right)$ merupakan informasi yang dapat membantu manajer memberikan pengetahuan yang lebih baik bagi manajer mengenai alternatif keputusan dan tindakan yang dibutuhkan untuk mencapai tujuan. Tersedianya informasi job relevant akan membantu manajer dalam membuat keputusan-keputus-an penting serta dapat membantu manajer untuk memprediksi keadaan lingkungan organisasi secara tepat.

\section{Populasi Penelitian}

Populasi sasaran dalam penelitian ini adalah seluruh Manajer pada Hotel ber bintang tiga di Kota Makassar berjumlah 22. Unit analisis yang sekaligus menjadi responden dalam penelitian ini adalah seluruh Manajer Food and 
Baverage.Adapun nama-nama hotel bintang tiga di Kota Makassar dapat dilihat dalam Tabel 1 sebagai berikut:

Tabel 1.

Daftar Hotel Bintang Tiga di Kota Makassar

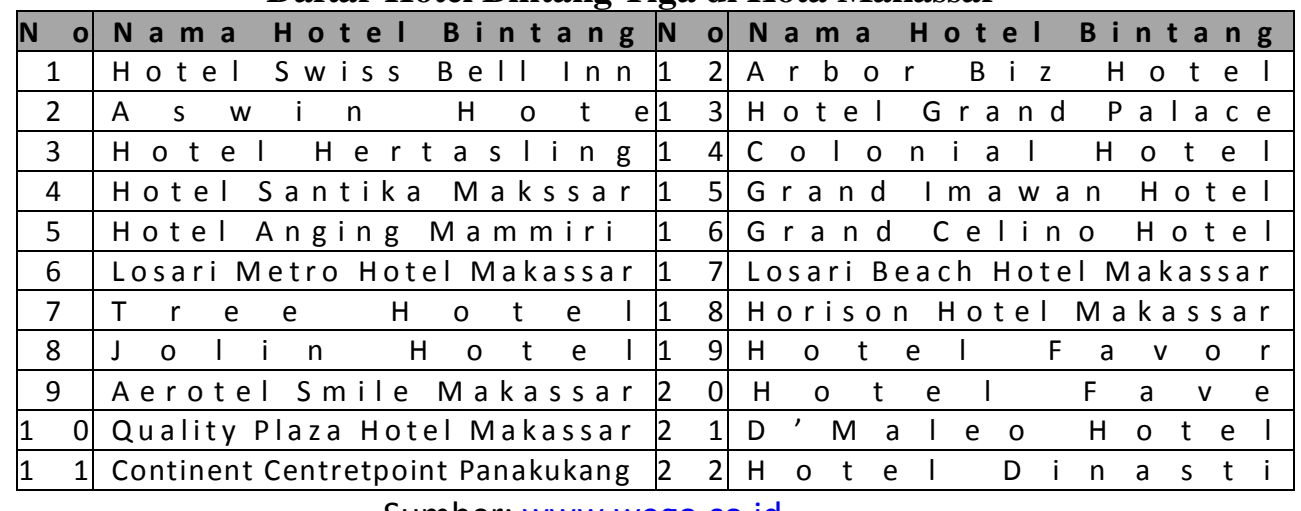

Sumber: www.wego.co.id

Metode sampel dalam penelitian in adalah metode sampling jenuh (sensus), dimana semua anggota populasi digunakan sebagai sampel, hal ini dilakukan mengingat jumlah populasi relatif kecil yaitu kurang dari 30 orang.

\section{Metode Pengumpulan Data}

Data dalam penelitian ini mengunakan data primer, yang diperoleh secara langsung dari sumber asli dengan menggunakan kuesioner. Kuesioner berisi pernyataan yang merupakan penjabaran dari operasionalisasi variabel ketidakpastian lingkungan, karakteristik anggaran, job relevant information, dan kinerja manajer. Pengukurannya, dengan menggunakan skala Likert dengan lima tingkatan kategori sebagai berikut :

$\begin{array}{lll}\text { SS } & =\text { Sangat Setuju } & \text { skor 5 } \\ \text { S } & =\text { Setuju } & \text { skor } 4 \\ \text { R } & =\text { Ragu-ragu } & \text { skor 3 } \\ \text { TS } & =\text { Tidak Setuju } & \text { skor 2 } \\ \text { STS } & =\text { Sangat Tidak Setuju } & \text { skor 1 }\end{array}$

\section{Uji Kualitas Data}

Ada dua konsep untuk mengukur kualitas data, yakni:

1. Uji Kesahihan (test of validity). Menggambarkan bagaimana kuesioner mampu mengukur apa yang ingin diukur, berdasarkan teoridan ahli. Semakin tinggi validitas suatu test maka alat test tersebut semakin tepat mengenai sasarannya.

2. Uji Keandalan (test of reliability). Untuk mengetahui apakah alat pengumpul data menunjukkan tingkat ketepatan, keakuratan, kestabilan, atau konsistensi alat tersebut dalam mengungkapkan gejala tertentu dari sekelompok individu.

\section{Uji Asumsi Klasik}

1. Uji Normalitas, bertujuan untuk menguji apakah dalam model regresi, variabel terikat dan variabel bebas keduanya mempunyai distribusi normal atau tidak. Model regresi yang baik adalah memiliki distribusi data normal atau mendekati normal. 
2. Uji Multikoliniearitas, bertujuan untuk menguji adanya korelasi variabelvariabel bebas antara yang satu dengan yang lainnya. Ada tidaknya terjadi multikoliniearitas dapat dilihat dari nilai VIF. Batasan nilai untuk dua variabel dikatakan berko-liniearitas tinggi bisa dilihat melalui nilai VIF (Variance Inflation Factors).

3. Uji Heteroskedastisitas, bertujuan untuk mendeteksi ada tidaknya pola tertentu pada grafik tertentu, dimana sumbu $\mathrm{Y}$ adalah $\mathrm{Y}$ yang telah diprediksi dan sumbu $\mathrm{X}$ adalah residual (Y-Prediksi-Y Sesungguhnya) yang distudentized.

\section{Metode Analisis Data}

Analisa data dalam penelitian ini dilakukan dengan menggunakan regresi linier berganda dengan persamaan sebagai berikut:

$$
\begin{array}{cl}
\text { Dimana: } & \multicolumn{1}{c}{\mathrm{Y}=\beta 0+\beta 1 \mathrm{X}_{1}+\beta 2 \mathrm{X}_{2}+\beta 2 \mathrm{X}_{3}+\varepsilon} \\
\mathrm{Y} & =\text { Kinerja Manajer } \\
\beta 0 & =\text { Intercept (konstanta) } \\
\beta 1 \beta 2 & =\text { Koefisien regresi. } \\
\mathrm{X}_{1} & =\text { Ketidakpastian lingkungan } \\
\mathrm{X}_{2} & =\text { Karakteristik Anggaran } \\
\mathrm{X}_{3} & =\text { Job Relevant Information } \\
\mathrm{e} & =\text { Residual Value atau variabel lain diluar variabel yang diteliti }
\end{array}
$$

Arti koefisien $\beta$ adalah jika nilai $\beta$ positif $(+)$ hal tersebut menunjukkan hubungan yang searah antara variabel bebas dengan variabel tidak bebas. Dengan kata lain peningkatan/penurunan variabel bebas akan disertai dengan peningkatan/penurunan variabel tidak bebas.

Sedangkan jika nilai $\beta$ negatif (-) hal tersebut menunjukkan hubungan yang berlawanan antara variabel bebas dengan tidak bebas. Setiap peningkatan variabel bebas akan diikuti dengan penurunan variabel tidak bebas, dan begitupun sebaliknya. Toleransi kesalahan $(\alpha)$ yang ditetapkan sebesar $5 \%$ dengan signifikansi sebesar $95 \%$.

\section{Statistik Deskriptif}

Statistik deskriptif digunakan untuk memberikan informasi mengenai karakteristik variabel penelitian dan demografi responden.Statistik deskriptif menjelaskan skala jawaban responden pada setiap variabel yang diukur dari maximum, minimum, rata-rata, dan standar deviasi.Disamping itu juga untuk mengetahui demografi yang terdiri dari kategori, jenis kelamin, tingkat pendidikan, dan sebagainnya (Imam, 2013).

\section{Pengujian Hipotesis}

Pengujian ini dilakukan untuk menguji variabel bebas terhadap variabel terikat. Menguji hipotesis tersebut dengan menggunakan statistik $t$, yaitu dengan membanding-kan $t_{\text {hitung }}$ dengan $t_{\text {tabel }}$ pada $\alpha=0,05$ dan derajat bebas (n-k-1) adalah jumlah variabel independen dengan kriteria keputusan:

- Jika nilai $\mathrm{t}_{\text {hitung }}<\mathrm{t}_{\text {tabel }}: \mathrm{H}_{0}$ diterima atau $\mathrm{H}_{1}$ ditolak 
- Jika nilai $\mathrm{t}_{\text {hitung }}>\mathrm{t}_{\text {tabel }}: \mathrm{H}_{1}$ diterima atau $\mathrm{H}_{0}$ ditolak

\section{PEMBAHASAN}

Hasil Uji Statistik Deskriptifh. Dengan menggunakan skala ordinal dengan jawaban antara 5 sampai dengan 1.

Tabel 2.

Hasil Uji Statistik Deskriptif

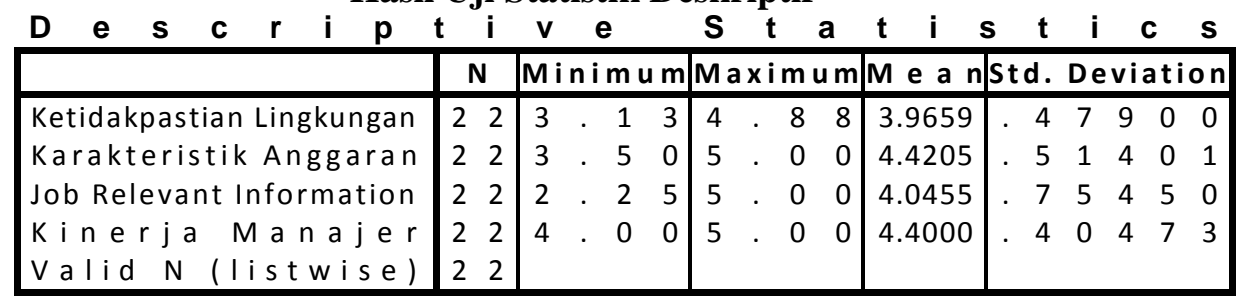

Sumber: Data primer yang diolah 2017

Pada Tabel 2 di atas dapat dilihat bahwa variabel kinerja manajer, dengan sampel 22 orang, jumlah total jawaban minimum responden, 4.00 dan total jawaban maximum 5.00 memiliki rata-rata 4.4000 dengan standar deviasi 0.40473. Variabel ketidakpastian lingkungan, dengan sampel 22 orang, jumlah total jawaban minimum responden, yaitu 3.13 dan total jawaban maximum 4.88 memiliki rata-rata 3.9659 dengan standar deviasi 0.47900. Variabel karakteristik anggaran, dengan sampel 22 orang, jumlah total jawaban minimum responden, yaitu 3.50 dan total jawaban maximum 5.00 memiliki rata-rata 4.4205 dengan standar deviasi 0.51401. Dan variabel job relevant information, dengan sampel 22 orang, jumlah total jawaban minimum responden, yaitu 2.25 dan total jawaban maximum 5.00 memiliki rata-rata 4.4000 dengan standar deviasi 0.75473 .

\section{Uji Kualitas Data}

\section{a. Hasil Uji Validitas}

Uji validitas ini dilakukan dengan membandingkan nilai $\mathbf{r}_{\text {hitung }}$ dengan nilai $\mathrm{r}_{\text {tabel }}$. Nilai $\mathrm{r}_{\text {hitung }}$ diambil dari output SPSS pada kolom Corrected Item-Total Correlation. Sedangkan nilai $\mathrm{r}_{\text {tabel }}$ dapat dilihat dengan bantuan tabel $\mathrm{r}$ pruduct moment jumlah sampel $-2(\mathrm{n}-2)$, sehingga $22-2=20=0,423$ (taraf signifikan $=$ 5\%). Untuk hasil lengkap dari uji validasi dapat dilihat pada Tabel 3 berikut:

\section{Tabel 3.}

Hasil Uji Validitas Ketidakpastian Lingkungan

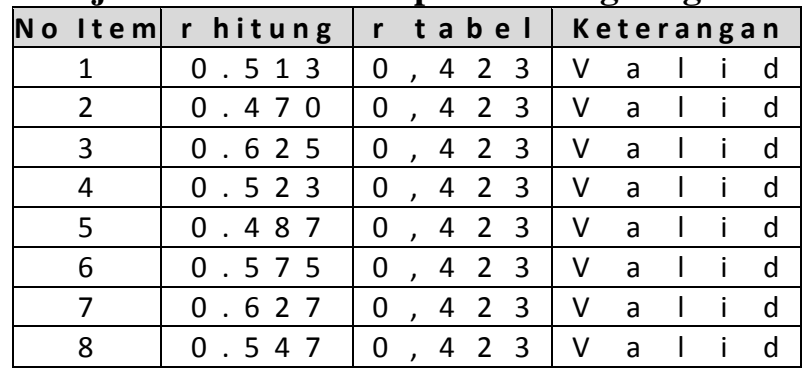

Sumber: Data primer yang diolah 2017 
Berdasarkan pada Tabel 3 dapat diketahui bahwa nilai korelasi $\mathrm{r}_{\text {hitung }}$ lebih besar dari $\mathrm{r}_{\text {tabel }} 0,423$ (taraf signifikan $=5 \%$ ), artinya item-item dari pernyataan tersebut dinyatakan valid dan dapat digunakan untuk pengambilan data.

\section{Tabel 4.}

Hasil Uji Validitas Karakteristik Anggaran

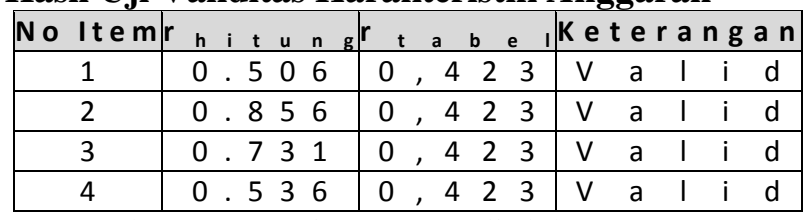

Sumber: Data primer yang diolah 2017

Berdasarkan pada Tabel 4 dapat diketahui bahwa nilai korelasi $r_{\text {hitung }}$ lebih besar dari $r_{\text {tabel }} 0,423$ (taraf signifikan $=5 \%$ ), artinya item-item dari pernyataan tersebut dinyatakan valid dan dapat digunakan untuk pengambilan data.

\section{Tabel 5.}

\section{Hasil Uji Validitas Job Relevant Information}

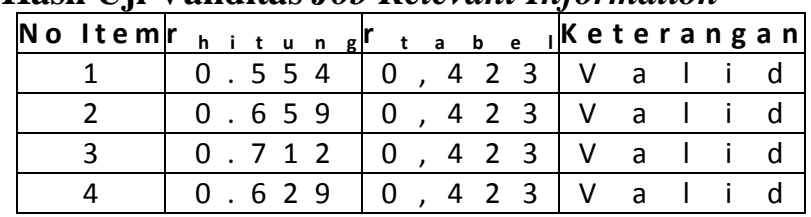

Sumber: Data primer yang diolah 2017

Berdasarkan pada Tabel 5 dapat diketahui bahwa nilai korelasi $r_{\text {hitung }}$ lebih besar dari $r_{\text {tabel }} 0,423$ (taraf signifikan $=5 \%$ ), artinya item-item dari pernyataan tersebut dinyatakan valid dan dapat digunakan untuk pengambilan data.

Tabel 6.

Hasil Uji Validitas Kinerja Manajer

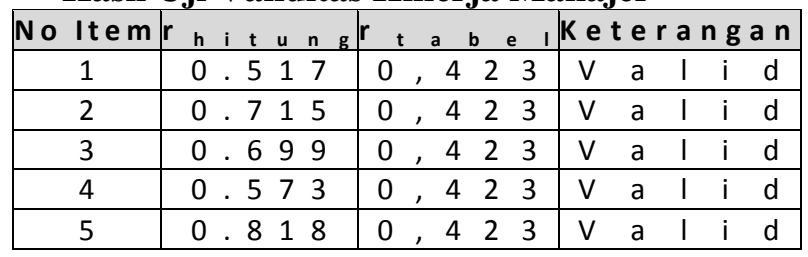

Sumber: Data primer yang diolah 2017

Berdasarkan pada Tabel 6 dapat diketahui bahwa nilai korelasi $\mathrm{r}_{\text {hitung }}$ lebih besar dari $r_{\text {tabel }} 0,423$ (taraf signifikan $=5 \%$ ), artinya item-item dari pernyataan tersebut dinyatakan valid dan dapat digunakan untuk pengambilan data.

\section{Hasil Uji Reliabitas}

Pengujian reliabilitas terhadap seluruh item/pertanyaan yang dipergunakan dalam penelitian ini akan menggunakan formula cronbach alpha (koefisien alphacronbach), dimana secara umum yang dianggap reliabel apabila nilai alpha cronbachnya $>0,6$. Hasil lengkap uji reliabilitas dapat dilihat pada Tabel 7 berikut ini:

Tabel 7

Hasil Uji Reliabilitas

\begin{tabular}{|lcccc|cccc|c|}
\hline $\mathbf{V}$ & $\mathbf{a}$ & $\mathbf{r}$ & $\mathbf{i}$ & $\mathbf{a}$ & $\mathbf{b}$ & $\mathbf{e}$ & $\mathbf{I}$ & \multicolumn{4}{|c|}{ Cronbach's } & Alpha & Keteranga n \\
\hline X1 (Ketidakpastian lingkungan) & 0 &. & 7 & 8 & 8 & R e I i a b e I \\
\hline X2 (Karakteristik Anggaran) & 0 &. & 7 & 7 & 1 & R e I i a b e I \\
\hline
\end{tabular}




\begin{tabular}{|l|lllll|l|}
\hline X3 (Job Relevant Information) & 0 &. & 8 & 0 & 4 & R e I i a b e I \\
\hline Y (K in e rja M a n a je r) & 0 &. & 8 & 4 & 8 & R e I i a b e I \\
\hline
\end{tabular}

Sumber: Data primer yang diolah 2017

Berdasarkan pada Tabel 7 diatas menunjukkan bahwa besarnya nilai Cronbach's Alpha pada seluruh variabel lebih besar dari 0,60, dan sesuai dengan standar dasar pengambilan keputusan,artinya semua item pernyataan tersebut reliabeldan dapat digunakan dalam penelitian.

\section{Hasil Uji Asumsi Klasik}

Sebelum dilakukan analisis regresi terhadap variabel-variabel penelitian terlebih dahulu dilakukan uji asumsi klasik. Tujuannya adalah agar data yang digunakan layak dijadikan sumber pengujian dan dapat dihasilkan kesimpulan yang benar. Uji asumsi klasik meliputi:

\section{a. Uji Normalitas}

Menguji data apakah terdistribusi secara normal atau tidak, dengan melihat Normal P-Plot of Regression Standardized Residual. Hasil pengujian ini dapat dilihat pada gambar di bawah ini :

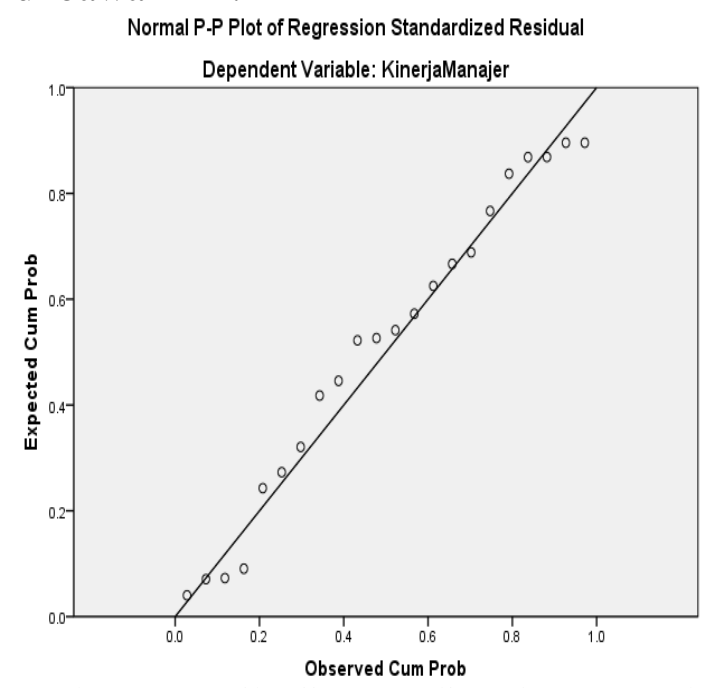

Gambar 2 : Hasil Uji Normalitas dengan P-Plot

Melihat grafik normal P-Plot di atas, terlihat titik-titik menyebar di sekitar garis diagonal, serta arah penyebarannya mengikuti arah garis diagonal, model regresi layak dipakai karena memenuhi asumsi normalitas.

\section{b. Uji Multikolinieritas}

Model regresi yang baik seharusnya tidak terjadi korelasi di antara variabel independen. Untuk menguji multikolinieritas dapat dilihat dari nilai tolerance dan nilai VIF (Variance Inflation Faktor). Berdasarkan nilai tolerance, nilai yang terbentuk harus di atas $10 \%$ dan bila menggunakan VIF, nilai yang terbentuk harus kurang dari 10, bila tidak maka akan terjadi multikolinieritas dan model regresi tidak layak untuk digunakan. Hasil pengujian multikolinieritas dapat dilihat pada tabel berikut ini. 
Tabel 8.

Hasil Uji Multikolinieritas

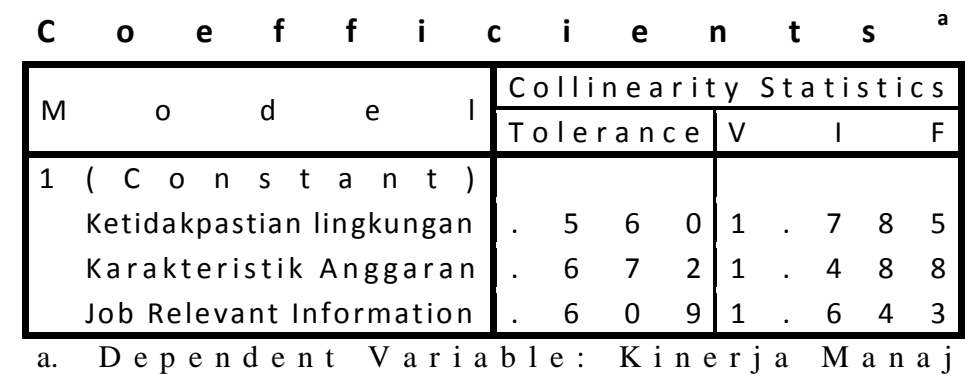

Sumber: Data primer yang diolah 2017

Hasil regresi pada Tabel 8 di atas, menunjukkan bahwa nilai VIF atau Variance Inflation Faktor variabel ketidakpastian lingkungan sebesar 1.785, karakteristik anggaran sebesar 1.488, dan job relevant information sebesar 1.777. Nilai-nilai tersebut semuanya kurang dari 10. Sedangkan nilai tolerance untuk variabel ketidakpastian lingkungan sebesar 0,560, karakteristik anggaran sebesar 0,672, dan job relevant information sebesar 0,609 yang lebih besar dari 10\% model regresi tidak ditemukan adanya korelasi antar variabel bebas (independen).

\section{c. Uji Heteroskedastitas}

Tujuan uji heteroskedastisitas ini adalah ingin mengetahui apakah dalam sebuah model regresi, terjadi ketidaksamaan varian pada residual (error) dari satu pengamatan ke pengamatan yang lain. Hasil pengujian heteroskedastisitas dapat dilihat pada gambar di bawah ini :

Scatterplot

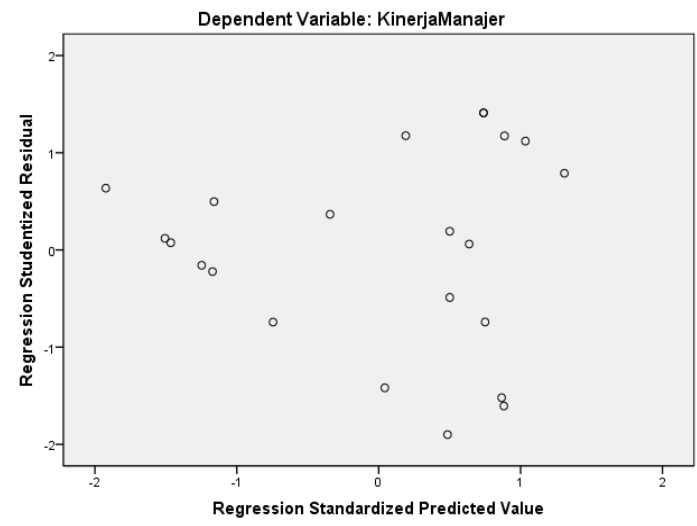

Gambar 3 : Hasil Uji Heteroskedastisitas

Dari grafik di atas, terlihat titik-titik menyebar secara acak, tidak membentuk sebuah pola tertentu yang jelas, serta tersebar baik di atas maupun di bawah angka 0 pada sumbu $Y$, artinya tidak terjadi heteroskedastisitas pada model regresi, sehingga model regresi layak digunakan untuk memprediksi kinerja manajer berdasarkan variabel yang mempengaruhinya, yaitu ketidakpastian lingkungan, karakteristik anggaran dan job relevant information.

\section{Hasil Uji Hipotesis}




\section{a. Uji Koefisien Determinasi (Adjusted $\mathbf{R}^{\mathbf{2}}$ )}

Hasil uji determinasi (Adjusted $R^{2}$ ) digunakan untuk menentukan seberapa besar variabel independen dapat menjelaskan variabel dependen, maka perlu diketahui nilai koefisien determinasi (Adjusted $R^{2}$ ). Adapun hasil uji determinasi (Adjusted $R^{2}$ ) dapat dilihat pada tabel berikut ini :

Tabel 9.

\section{Hasil Uji Koefisien Determinasi (Adjusted $\mathbf{R}^{2}$ )}

Model Summary

\begin{tabular}{|c|c|c|c|c|c|c|}
\hline Mod e I & $\mathrm{R}$ & $R$ & $\mathrm{Square}$ & e Adjusted & R Square & Std. Error of the Estimate \\
\hline 1 & $.709^{\mathrm{a}}$ & & $\begin{array}{lll}5 & 0 & 2\end{array}$ & 4 & 1 & $\begin{array}{lllll}3 & 0 & 8 & 4 & 1\end{array}$ \\
\hline
\end{tabular}

Sumber: Data primer yang diolah 2017

Berdasarkan Tabel 9 di atas menyatakan bahwa nilai koefisien determinasi yang sudah disesuaikan (Adjusted $R$ Square) adalah 0,419.Berarti 41,9\% variasi dari kinerja manajer bisa dijelaskan oleh variasi variabel independen (ketidakpastian lingkungan, karakteristik anggaran dan job relevant information). Sedangkan sisanya $(100 \%-41,9 \%=58,1 \%)$ dijelaskan oleh variabel lain yang tidak ada dalam penelitian ini.

\section{b. Uji Parsial (Uji t)}

Uji t menunjukkan seberapa jauh pengaruh satu variabel independen secara individual dalam menerangkan variasi variabel dependen dan digunakan untuk mengetahui ada atau tidaknya pengaruh masing-masing variabel independen secara individual terhadap variabel dependen yang diuji pada tingkat signifikansi 0,05 . Hasil pengujiannya dapat dilihat pada tabel berikut:

Tabel 10.

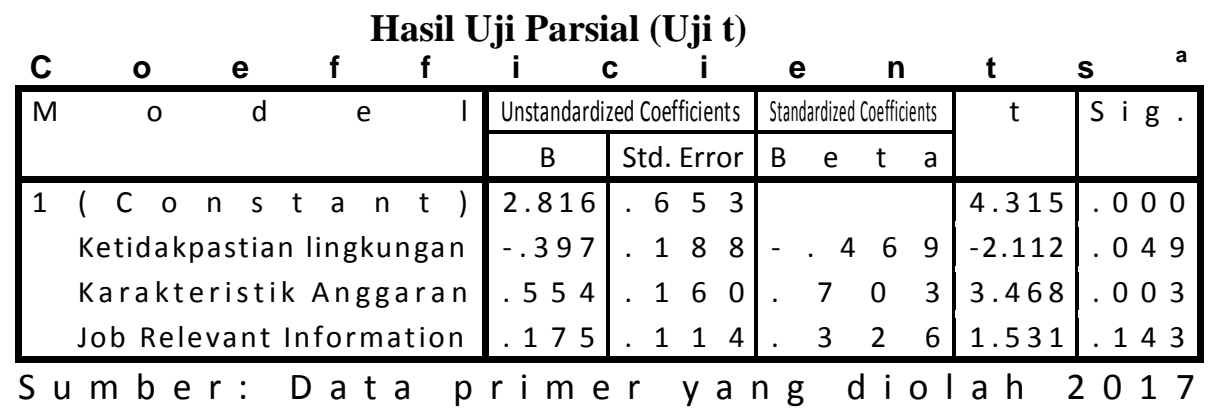

Berdasarkan Tabel 10 di atas hasil yang telah diperoleh dari koefisien regresi di atas, maka dapat dibuat suatu persamaan regeresi sebagai berikut:

$$
\mathrm{Y}=2,816-0,397 \mathrm{X} 1+0,554 \mathrm{X} 2+0,175 \mathrm{X} 3
$$

Pada persamaan regresi di atas menunjukkan nilai konstanta sebesar 2,816. Hal ini menyatakan bahwa jika variabel ketidakpastian lingkungan, karakteristik anggaran dan job relevant information dianggap konstan atau bernilai 0 (nol), maka kinerja manajer food andbaverage akan meningkat sebesar 2,816.

Koefisien regresi pada variabel ketidakpastian lingkungan sebesar -0,397, hal ini berarti jika variabel ketidakpastian lingkungan bertambah satu satuan maka variabel kinerja manajer food and baverage akan menurun sebesar 0,397.

Koefisien regresi pada variabel karakteristik anggaran sebesar 0,554, hal ini berarti jika variabel karakteristik anggaran bertambah satu satuan maka variabel 
kinerja manajer food and baverage akan meningkat sebesar 0,554 dengan catatan variabel lain dianggap konstan.

Koefisien regresi pada variabel job relevant information sebesar 0,175 , hal ini berarti jika variabel job relevant information bertambah satu satuan maka variabel kinerja manajer food and baverage akan meningkat sebesar 0,175 dengan catatn variabel lain dianggap konstan.

Melalui statistik uji-t yang terdiri dari ketidakpastian lingkungan $\left(\mathrm{X}_{1}\right)$, karakteristik anggaran $\left(\mathrm{X}_{2}\right)$ dan job relevant information $\left(\mathrm{X}_{3}\right)$ dapat diketahui secara parsial pengaruhnya terhadap kinerja manajer food and baverage (Y).

1. Pengujian Hipotesis Pertama $\left(\mathrm{H}_{1}\right)$.

Berdasarkan perhitungan SPSS pada Tabel 10 di atas, variabel ketidakpastian lingkungan dengan nilai sig. lebih kecil dari $0,05(0,049<0,05)$, artinya terdapat pengaruh yang signifikan dari ketidakpastian lingkungan terhadap kinerja manajer food and baverage.

2. Pengujian Hipotesis kedua $\left(\mathrm{H}_{2}\right)$

Berdasarkan perhitungan SPSS pada Tabel 10 di atas, variabel karakteristik anggaran dengan nilai sig. lebih kecil dari $0,05(0,003<0,05)$, artinya terdapat pengaruh yang signifikan dari karakteristik anggaran terhadap kinerja manajer food and baverage.

3. Pengujian Hipotesis ketiga $\left(\mathrm{H}_{3}\right)$

Berdasarkan perhitungan SPSS pada Tabel 10 di atas, variabel job relevant information dengan nilai sig. lebih besar dari 0,05 $(0,143>0,05)$, artinya tidak terdapat pengaruh yang signifikan dari job relevant information terhadap kinerja manajer food and baverage.

\section{PEMBAHASAN}

\section{Pengaruh Ketidakpastian Lingkungan terhadap Kinerja Manajer.}

Hasil penelitian menunjukkan bahwa ketidakpastian lingkungan berpengaruh negatif dan signifikan terhadap kinerja manajer food and baverage. Variabel ketidakpastian lingkunganbertanda negatif yang menunjukkan adanya hubungan yang berlawanan arah dengan kinerja manajer.Hal ini menjelaskan bahwa ketidakpastian lingkungan bisnis menyebabkan stabilitas ekonomi terganggu yang berdampak pada kemampuan dan daya beli masyarakat menurun. Tentunya akan berpengaruh terhadap kebijakan tertnetu untuk mengunjungi hotel, termasuk berdampak pada restoran hotel. Hasil ini didukung oleh penelitian yang dilakukan Miah (1996) yang menunjukan bahwa ketidakpastian lingkungan berpengaruh negatif terhadap kinerja manajerial.Pengaruh negatif mengartikan bahwa semakin tinggi tingkat ketidakpastian lingkungan bisnis semakin menurun kinerja manajer.

\section{Pengaruh Karakteristik Anggaran Terhadap Kinerja Manajer.}

Hasil penelitian menunjukkan bahwa karakteristik anggaranberpengaruh positif dan signifikan terhadap kinerja manajer food and baverage. Ada keinginan yang mendorong manajer melakukan suatu usaha secara maksimal untuk mewujudkan kondisi yang diharapkan, guna mencapai tujuan individu dan organisasi. Dorongan itu merupakan penghargaan, dan keinginan prestasi kerja 
yang ingin ditunjukkan untuk mencapai sasaran target kerja yang ditentukan. Hal ini bisa dicapai dengan karakteristik anggaran para manajer cenderung tinggi terhadap pekerjaan dan organisasinya. Bambang (2007) menyatakan bahwa karakteristik anggaran mempunyai pengaruh yang signifikan terhadap kinerja karyawan.

Penelitian yang dilakukan oleh Citra (2006) yang menyatakan peningkatan karakteristik tujuan anggaran semakin meningkatkan kinerja manajerial. Semakin baik partisipasi dalam menyusun anggaran, melaksanakan anggaran, dan mempertanggung-jawabkan anggaran sesuai dengan arah kebijakan umum, strategi dan prioritas, visi dan misi, tujuan dan fungsi instansi, serta sasaran dan tujuan dari masing-masing instansi maka kinerjanya dianggap baik.

Secara keseluruhan penelitian ini menunjukkan bahwa manajemen tingkat atas mampu meningkatkan kinerja manajerial dari manajer tingkat bawah dengan penekanan pada partisipasi penyusunan anggaran dan kejelasan tujuan anggaran dalam penentuan tujuan anggaran.

\section{Pengaruh Job Relevant Information terhadap Kinerja Manajer.}

Hasil penelitian menunjukkan bahwa job relevant information berpengaruh positif dan tidak signifikan terhadap kinerja manajer food and baverage. Hal ini disebabkan job relevant information yang peroleh perusahaan masih dirasakan tidak simetris dan tidak sesuai dengan harapan manajer sehingga kurang meningkatkan kinerjanya. Hal ini menunjukan bahwa imbalan yang diberikan oleh hotel kepada manajer belum sesuai kinerja yang dilakukan manajer.

Hal itu sejalan dengan penelitian Indarto (2011) yang menyimpulkan bahwa job relevant information tidak berpengaruh secara signifikan, Hal sama juga di ungkapkan Yusfaningrum (2005) menyatakan job relevant information berpengaruh tidak signifikan terhadap kinerja karyawan. Job relevant information merupakan balas jasa yang diberikan perusahaan kepada karyawan. Job relevant information yang diberikan perusahaan harus dirasakan adil bagi karyawan dan besarnya kompnsasi harus sesuai dengan yang diharapkan karyawan. Sehingga dapat disimpulkan bahwa besarnya job relevant information yang diberikan perusahaan masih dirasakan tidak adil dan tidak sesuai dengan harapan karyawan.

Hal ini membuktikan bahwa job relevant information menjadi faktor yang tidak mempengaruhi kinerja manajer food and baverage.Berdasarkan hasil uji regresi linier berganda ditemukan hasil positif dan tidak signifikan hal ini membuktikan bahwa job relevant information kurang berarti dalam mempengaruhi kinerja.

\section{PENUTUP}

\section{Simpulan}

Berdasarkan data yang diperoleh maupun hasil pengujian yang telah dilakukan dengan menggunakan regresi berganda maka dapat ditarik beberapa kesimpulan, sebagai berikut:

1. Ketidakpastian lingkunganmemperlihatkan hubungan berlawanan dengan kinerja manajer, artinyaketidakpastian lingkungan bisnis menyebabkan perubahan-perubahan kebijakan tertentu yang berdampak terhadap jumlah 
junjungan hotel. Semakin tinggi tingkat ketidakpastian lingkungan bisnis semakin menurun kinerja manajer.

2. Karakteristik anggaran berpengaruh terhadap kinerja manajer food and baverage. Suatu dorongan merupakan penghargaan, dan keinginan prestasi kerja yang ingin ditunjukkan untuk mencapai sasaran target kerja yang ditentukan. Hal ini bisa dicapai dengan karakteristik anggaran yang tinggi. Partisipasi, pelaksanaan, dan pertanggungjawaban anggaran yang baik akan mendorong terwujudnya kinerja yang baik.

3. Job relevant information berpengaruh,namun tidak signifikan terhadap kinerja manajer food and baverage. Job relevant information yang peroleh perusahaan masih dirasakan tidak simetris dan tidak sesuai dengan harapan manajer sehingga kurang meningkatkan kinerjanya.Job relevant information kurang berarti dalam mempengaruhi kinerja.

\section{Saran}

1. Diharapkan penelitian selanjutnya akan memperluas variabel yang berpengaruh terhadap kinerja manajer.

2. Penelitian ini terbatas pada objek penelitian manajer food and baverage. Diharapkan kedepan, akan dilakukan pada manajer house keeping.

3. Penelitian selanjutnya disarankan menggunakan penelitian dengan pendekatan kualitatif, yang akan mengkaji secara mendalam dengan menggunakan dirinya sendiri sebagai instrument penelitian.

\section{DAFTAR PUSTAKA}

Anwar Prabu Mangkunegara, 2012. Evaluasi Kinerja SDM. Bandung: Refika Aditama.

Arfan Ikhsan dan Muhammad Ishak. 2010. Akuntansi Keperilakuan. Jakarta: Salemba Empat.

Bambang Sardjito, Osmad Muthaher, 2007. Pengaruh Partisipasi Penyusunan Anggaran terhadap Kinerja Aparat Pemerintah Daerah: Budaya Organisasi dan Komitmen Organisasi sebagai Variabel Moderating. Simposium Nasional Akuntansi (SNA) X. UNHAS Makasar, 26-28 Juli.

Chenhall, Robert H. dan Deigan Morries. 1986. "The Impact of Structure, Environment, and Interdependence on the Perceived Usufulness of Management Accounting Systems". Accounting Review. pp. 16-35.

Citra Paramita, Komang. 2006. "Pengaruh Budgetary Goal Charateristics terhadap Kinerja Manajerial dengan Budaya Paternalistik dan Komitmen Organisasi Sebagai Variabel Moderating pada Perusahaan Cargo di Kota Denpasar". Fakultas Ekonomi, Universitas Udayana Denpasar.

Chong, V. K. dan K. M. Chong. 2002. Budget Goal Commitment and Informational Effects of Budget Participation on Performance: A Structural Equation Modeling Approach. Behavioral Research In Accounting14: 6586.

Eko Madyo Susanto, Rosita., 2012. Pengaruh Informasi Akuntansi Terhadap Kinerja Manajer (Studi Empiris Pada Manajer Koperasi Se-Eks 
Karesidenan Surakarta.Jurnal Akuntansi dan Sistem Teknologi Informasi Vol. 9, No. 1, Oktober 2 2012: 1 - 10

Gerloff, Edwin A. 1985. Organizational Theory and Design - A Strategic Approach for Management, New York: Mc. Graw-Hill.

Ginanjar Apriyansyah, Zirman, Rusli. 2014. Pengaruh Partisipasi Anggaran, Komitmen Organisasi, Kepuasan Kerja, Job Relevant Information dan Budaya Organisasi Terhadap Kinerja Manajerial Pada perhotelan Di Provinsi Riau. JOM, Fekon, Vol.1. NO,2, Oktober,2014.

Gordon, Lawrence A. and V.K. Narayanan. 1984. "Management Accounting Systems, Perceived Environmental Uncertainty and Organization Structure: An Empirical Investigation". Accounting, Organizations and Society. Vol.9, No.1. pp. $259-285$.

Gul Ferdinand A., 1991. The Effects of Management Accounting Systems and Environmental Uncertianty on Small Business Manager's Performance, Accounting and Business Research, Vol 22, No.85, pp. 57-71.

Imam Ghozali, 2013. "Aplikasi Analisis Multivariate Dengan Program. SPSS". Semarang.

I Made Narsa, Rani Dwi Yuniawati, 2003. Pengaruh Interaksi Antara Total Quality Management Dengan Sistem Pengukuran Kinerja dan Sistem Penghargaan Terhadap Kinerja Manajerial (Studi Empiris Pada PT. Telkom Divre V Surabaya). Jurnal Akuntansi \& Keuangan Vol. 5, No. 1, Mei 2003: $18-34$

Indarto, S. L., Ayu S. D. 2011. Pengaruh Partisipasi dalam Penyusunan Anggaran terhadap Kinerja Manajerial Perusahaan Melalui Kecukupan Anggaran, Komitmen Organisasi, Komitmen Tujuan Anggaran dan Job Relevant Information. Seri Kajian Ilmiah 14(1): 1-44.

Kenis, Izzettin,1979.Effects of Budgetary Goal Characteristics on Managerial Attitudes and Performance. The Accounting Review. Hal 707- 721.

Kren, L. 1992. Budgetary Participation and Managerial Performance: The Impact of Information and Environmental Volatility. The Accounting Review67(3): 511-526.

Munawar, 2006. Pengaruh Karakteristik Tujuan Anggaran Terhadap Perilaku, Sikap, dan Kinerja Aparat Pemerintah Daerah Di Kabupaten Kupang. Simposium Nasional Akuntansi 9 Padang.

Maryanti, H., A., 2002. Pengaruh Karakteristik Tujuan Anggaran terhadap Perilaku, Sikap, dan Kinerja Pemerintah Daerah di propinsi Nusa Tenggara Timur. (tesis)

Miah, N. Z., Lokman Mia, 1996. Decentralization, Accounting Control and Performance of Government Organization: A New Zealand Empirical Study. Financial Accountibility \& Management. Agustus, pp. 173-189.

Milliken, F. J, 1987. Three Type of Perceived Uncertainty About Environment: State, Effect and Response Uncertanty. Academy of Management Review. Vol. 12 pp 133-143.

Nor Wahyudin, 2007. Desentralisasi dan Gaya Kepemimpinan sebagai Variabel Moderating Dalam Hubungan Antara Partisipasi Penyusunan Anggaran 
dan Kinerja Manajerial. Simposium Nasional Akuntansi X. Makasar. Hal. $1-27$.

Podrug, Najla, 2011. The Strategic Role Of Managerial Stewardship Behavior For Archieving Corporate Citizenship. Ekonomski Pregled. Vol. 62 (7-8).

Porter, M. E, 1979. How Competitive Forces Shape Strategy. Harvard Business Review, March-April. Pp 137-145.

Ratna Pujiyanti, 2009. "Pengaruh Partisipasi Penyusunan Anggaran terhadap Kinerja Manajerial dengan Variabel Moderating Transparasi Kebijakan Publik Pada Satuan Kerja Pemerintah Daerah (SKPD) di Kabupaten Semarang". Fakultas Ekonomi, Universitas Negeri Semarang.

Rosidi. 2000. Partisipasi dalam Penganggaran dan Prestasi Manajer: Pengaruh Komitmen Organisasi dan Informasi Job Relevant. Jurnal Ekonomi danManajemen1(1): 1-15.

Selfi Samadara, 2016. Faktor Penentu Kinerja Manajerial (Studi pada Pemerintah Daerah Kupang). Iqtishadia, Vol. 9, No. 1

Suharsimi Arikunto, 2006. Prosedur Penelitian Suatu Pendekatan Praktik. Edisi Revisi VI. Jakarta : PT. Rineka Cipta. 